\title{
Effects of Two Different Feeding Strategies During Dry-off on Certain Health Aspects of Dairy Cows
}

\author{
M. O. Odensten, ${ }^{* 1}$ K. Holtenius, ${ }^{*}$ and K. Persson Waller†‡ \\ ${ }^{*}$ Department of Animal Nutrition and Management, Swedish University of Agricultural Sciences, SE-753 23 Uppsala, Sweden \\ †Department of Pigs, Poultry and Ruminants, National Veterinary Institute (SVA), SE-751 89 Uppsala, Sweden \\ ‡Department of Clinical Sciences, Swedish University of Agricultural Sciences, SE-750 07 Uppsala, Sweden
}

\section{ABSTRACT}

With increasing milk production and short calving intervals, high daily milk yields at dry-off are rather common, making the dry-off procedure difficult and increasing the risk for health problems during the dryoff period. The objective of the following study was to compare the effects of 2 dry-off protocols, using different nutrient supplies, on health, as measured by clinical findings, intramammary infections, milk somatic cell count, and plasma concentrations of cortisol, serum amyloid $\mathrm{A}$, haptoglobin, and $\mathrm{Mg}$, in dairy cows. Twentyone primi- and multiparous dairy cows were randomly assigned to 2 different feeding treatments. One group was fed ad libitum straw (straw), whereas the other group was fed $4 \mathrm{~kg}$ of DM silage daily and ad libitum straw (silage) during dry-off (i.e., for $5 \mathrm{~d}$ ). All cows were milked in the morning of $\mathrm{d} 3$ and 5 during this period. At the start of dry-off (d 0$)$, the average daily milk yield was $17.1 \pm 0.8 \mathrm{~kg}$. The plasma cortisol concentration increased during dry-off only in cows fed straw. There was no significant effect of treatment on plasma serum amyloid $\mathrm{A}$, but the concentration increased during dryoff in both groups. The plasma $\mathrm{Mg}$ concentration decreased during dry-off, and the values tended to be lower in the straw group. The milk somatic cell count increased in both groups during dry-off but did not differ between groups. In both groups the heart rate decreased at dry-off, but the decrease was more pronounced in the straw group. Overall, this study (together with a previous report) shows that the common dry-off procedure of feeding straw only may give rise to metabolic disturbances. However, this might be avoided without any apparent negative effects on udder health if a limited amount of silage is added during dry-off.

Key words: dry-off, udder health, cortisol, acute phase protein

Received June 13, 2005.

Accepted October 5, 2006

${ }^{1}$ Corresponding author: Martin.Odensten@huv.slu.se

\section{INTRODUCTION}

With increasing milk production and calving intervals around 12 to $13 \mathrm{mo}$, high yields at dry-off are not uncommon, making the dry-off procedure difficult (Dingwell et al., 2001). At dry-off it is of vital importance that milk synthesis be rapidly inhibited to avoid negative effects on udder health (Dingwell et al., 2004). To reduce milk production, different strategies can be used, including reducing available feed nutrients and milking less frequently (Skidmore et al., 1997). However, specific recommendations on how to manage the dry-off procedure of high-producing cows in the best way are scarce. Some farmers have adopted dry-off routines involving short-term drastic reductions in feed supply, but concerns have been raised that major changes in the nutrient supply at dry-off might lead to metabolic problems, especially among high-yielding cows (Skidmore et al., 1997). In a previous report (Odensten et al., 2005), cows fed straw only at dry-off responded with increased plasma NEFA concentrations, increased ruminal fluid $\mathrm{pH}$, and decreased ruminal VFA concentrations compared with cows fed silage and straw, which may support the concerns raised. Moreover, the changes in the ruminal fluid may give rise to a reduction in $\mathrm{Mg}$ absorption from the rumen and hypomagnesemia (Giduck and Fontenot, 1987; Giduck et al., 1988).

The most common health problem associated with dry-off is IMI, which mostly are unobserved until after calving, when clinical mastitis occurs (reviewed by Dingwell et al., 2004). The risk for IMI at dry-off increases with increasing milk production at dry-off, the occurrence of milk leakage, decreasing teat end integrity, and late formation of the teat-canal keratin plug (Jørstad et al., 1989; Dingwell et al., 2001, 2004). The susceptibility to IMI is also influenced by the quality of the immune defense of individual cows, for example, the antibacterial functions of immune cells. Metabolic disturbances, as well as other stressors, can have negative effects on important immune cell functions, which may increase the susceptibility to infectious diseases such as mastitis (Preisler et al., 1999; Suriyasathaporn 
et al., 2000). However, the relationship between immune functions and metabolism in dairy cows has mainly been studied in the periparturient and early lactation periods.

Clinical health disorders can be diagnosed using clinical examination combined with various diagnostic tests. However, recording of subclinical diseases is also of great interest. During recent years, several studies have shown that acute phase proteins (APP) can be used as indicators of both clinical and subclinical diseases in cattle (Alsemgeest et al., 1994). Acute phase proteins are proteins produced, mainly in the liver, as a response to external or internal challenges, such as infection and inflammation, surgical trauma, or stress. In cattle, serum amyloid A (SAA) and haptoglobin (Hp) are the most important APP (Murata et al., 2004). According to Murata et al. (2004), the serum concentrations of APP are related to the severity of the disease and the extent of tissue damage in the affected animal, and the concentrations return to very low levels when the triggering factor (i.e., the factor that initiated the acute phase response) is no longer present (Petersen et al., 2004).

Major changes in the nutrient supply at dry-off might lead to metabolic and infectious disorders among dairy cows. The objective of the following study was to compare the effects in dairy cows of 2 dry-off protocols, using different nutrient supplies, on health and stress, as measured by clinical findings, IMI, milk SCC, and concentrations of cortisol, SAA, Hp, and Mg in plasma. We wanted to test the hypotheses that feeding straw only at dry-off would result in an increased risk for metabolic disturbances but an improved udder health, compared with feeding straw plus $4 \mathrm{~kg}$ of DM silage.

\section{MATERIALS AND METHODS}

\section{Animals, Management, and Experimental Design}

Twenty-one primiparous $(\mathrm{n}=12)$ and multiparous $(n=9)$ dairy cows of the Swedish Red and White breed were included in this experiment. The cows were bred with sires that were indexed for high $(\mathbf{H F I} ; \mathrm{n}=11)$ and low (LFI; $\mathrm{n}=10)$ milk fat percentage but the same amount of energy produced in milk. The cows were selected based on their milk yield and udder health 1 wk prior to the start of dry-off. The criteria were a yield of at least $15 \mathrm{~kg} / \mathrm{d}$ of milk and composite milk SCC below 100,000 cells $/ \mathrm{mL}$. The full experimental design is presented in Odensten et al. (2005). The actual dryoff procedure lasted for $5 \mathrm{~d}$ and is referred to as dryoff (d 1 to 5 ). The first day of dry-off (d 1) was approximately 8 wk prior to estimated parturition. The experiment started $1 \mathrm{wk}$ before d 1 and lasted 3 wk after d 1 (i.e., a total of $4 \mathrm{wk}$ ). The cows were randomly assigned to 2 different dry-off diets, ad libitum straw (straw, $\mathrm{n}=$ 10) or ad libitum straw plus $4 \mathrm{~kg}$ of DM silage (silage, $\mathrm{n}=11$ ). These diets were fed $\mathrm{d} 1$ to 5 . All cows were also fed $300 \mathrm{~g}$ of a mineral mix, which contained $65 \mathrm{~g}$ of magnesium per $\mathrm{kg}$. The cows were milked twice daily $(0500$ and $1600 \mathrm{~h})$ the week before dry-off and on 2 occasions during dry-off, at $0500 \mathrm{~h}$ on d 3 and 5 .

Individual clinical examinations were performed on $\mathrm{d} 4$ during the week prior to dry-off and on d 5 during dry-off. The clinical examination included heart rate, rectal temperature, and frequency of rumen contractions. The rumen contractions were registered using a stethoscope, and the number of contractions per $5 \mathrm{~min}$ was counted. The disease incidence was recorded during the whole study period. Body condition score was assessed the week before the cows entered the trial and at $2 \mathrm{wk}$ before expected parturition. The experimental design was approved by the Uppsala Local Ethics Committee.

\section{Samplings and Analyses}

Feed. Silage and concentrate samples were collected once weekly. The weekly samples were merged prior to analysis. Straw samples were collected every day whenever straw was included in the diet. Feed sample analyses and results are reported in Odensten et al. (2005).

Milk. Measurements of daily milk yield (sum of morning and evening milkings, $\mathrm{kg} / \mathrm{d}$ of milk) and cow composite milk SCC (Fossomatic, Hillerød, Denmark) for each cow were performed once weekly at 4 wk prior to dry-off and at $6 \mathrm{wk}$ after parturition. In addition, measurements were performed on 4 occasions during the week before dry-off and during dry-off: evening milkings on $d-6$ and -3 , and morning milkings on $d$ -5 and -2 before dry-off, and at the 2 milkings during dry-off.

Udder quarter milk samples were collected aseptically using Mastistrip (Department of Mastitis and Diagnostic Products, National Veterinary Institute, Uppsala, Sweden) immediately after the morning milkings on $d-6,-3,3$, and 5 . In addition, udder quarter milk samples were also collected postparturition (PP), that is, after the morning milking on 2 occasions (PP1 and PP2), at least $2 \mathrm{~d}$ apart, between 4 and $8 \mathrm{~d}$ PP. All quarter milk samples were analyzed for bacteriological growth and ATP concentration (as an indicator of SCC; Olsson et al., 1986) using accredited methods of the Section of Mastitis, National Veterinary Institute, Uppsala, Sweden. Levels of ATP $>2 \times 10^{-10} \mathrm{~mol} / \mathrm{mL}$ were considered elevated. An IMI was defined as a bacteriological finding of major or minor udder pathogens on at least 1 of 2 sampling occasions per period (before 
dry-off, during dry-off, and PP). Major pathogens were all udder pathogens other than the minor udder pathogens Corynebacterium bovis and CNS.

Blood. Daily blood samples were collected on d -5 , $-4,-2,1,2,3,4,5,6,7,8,10,12,15$, and 19 from the jugular vessel into evacuated tubes containing sodium heparin as anticoagulant (Venoject; Terumo Europe N.V., Leuven, Belgium). The blood sampling was performed between 1000 and $1100 \mathrm{~h}$ each day. On 2 occasions, once during the week before dry-off $(\mathrm{d}-5)$ and once during the dry-off week (d 2), blood samples were collected every second hour for $24 \mathrm{~h}$ starting at $1000 \mathrm{~h}$. Approximately $3 \mathrm{~h}$ before the start of this sampling, the cows were fitted with a semipermanent catheter (Milacath, no. 1411; Mila International Inc., Florence, $\mathrm{KY}$ ) in the jugular vein. All blood samples were kept on ice until centrifuged ( $8 \mathrm{~min}$ at $1,800 \times \mathrm{g}$ ) within $1 \mathrm{~h}$ after sampling. The plasma was stored at $-20^{\circ} \mathrm{C}$ until analyzed for cortisol, Hp, SAA, and Mg. Cortisol was analyzed using a commercial kit (Coat-A-Count; Diagnostic Products Corporation, Los Angeles, CA). Concentrations of $\mathrm{Hp}$ and SAA in plasma were determined using commercially available ELISA (bovine haptoglobin assay and phase serum amyloid A assay; Tridelta Development Ltd., Greystones, Wicklow, UK) with the addition of some extra data points to the SAA standard curve. The detection range was 15.6 to $2605.0 \mathrm{mg} / \mathrm{L}$ for $\mathrm{Hp}$ and 2.3 to $150.0 \mathrm{mg} / \mathrm{L}$ for SAA. Plasma concentrations of $\mathrm{Mg}$ were analyzed using a quantitative colorimetric method (MAG-275-02; Horizon Diagnostics Inc., San Antonio, TX).

\section{Statistical Analysis}

Statistical ANOVA was performed on data using PROC MIXED (version 8.02; SAS Institute, Inc., Cary, $\mathrm{NC)}$. Least squares means were compared with the comparison-wise error rate after significant $F$-tests. Least significant difference values were based on calculations with $t_{0.975}$. Two different models were used to analyze these data, as shown below. These models used different variances between subjects for the 3 period classes and different autoregressive covariance structures for the within-subject variations. The models were tested for significant fixed effects and interactions, and nonsignificant fixed effects and interactions $(P>0.05)$ were excluded from the models. The interaction between treatment and day was kept in the models to obtain least squares means and standard errors of the mean for the different parameters. Values shown in the text are presented as least squares means \pm standard errors of the mean, unless otherwise stated.

Using model 1, statistical analyses of heart rate, rectal temperature, rumen contractions, BCS, and diurnal cortisol profile were performed on individual cow values. In this model the sample prior to dry-off was used as a covariate. In the model for the diurnal cortisol profiles, the calculations were conducted on 12 samples from each sample day. The effect of SL was added in the model for analyzing the diurnal profile of plasma cortisol:

$$
\mathrm{y}_{\mathrm{ijk}}=\mu+\tau_{\mathrm{i}}+\gamma_{\mathrm{j}}+\beta \mathrm{x}_{\mathrm{ijk}}+\varepsilon_{\mathrm{ijk}}
$$

where $\mu$ is the measurement of heart, rectal temperature, rumen contractions, BCS, and diurnal cortisol profile during dry-off; $\tau_{\mathrm{i}}$ is the effect of treatment ( $\mathrm{i}=$ straw, silage); $\gamma_{\mathrm{j}}$ is the effect of date of expected parturition $(\mathrm{j}=1,2,3,4,5,6) ; \mathrm{x}_{\mathrm{ijk}}$ is the corresponding mean prior to dry-off used as a covariate; and $\varepsilon_{\mathrm{ijk}} \sim \mathrm{N}\left(0, \sigma^{2}\right)$ is random error $\left(\mathrm{k}=1, \ldots \mathrm{n}_{\mathrm{ij}}, 1 \leq \mathrm{n}_{\mathrm{ij}} \leq 3\right)$. The complete model was reduced using a stepwise backward elimination procedure in which the explanatory variables were tested for significance $(P<0.05)$.

The statistical analyses of plasma parameters (daily plasma cortisol, $\mathrm{Mg}$, and SAA) were performed using model 2:

$$
\mathbf{y}_{\mathrm{ijklm}}=\mu+\tau_{\mathrm{i}}+\gamma_{\mathrm{j}}+\rho_{\mathrm{k}}+\mathbf{S}_{\mathrm{l}}+\mathbf{d}_{\mathrm{t}}+\tau \rho_{\mathrm{ik}}+\varepsilon_{\mathrm{ijklm}}
$$

where $\mu$ is the overall mean, $\tau_{\mathrm{i}}$ is the effect of treatment [i = straw (1), silage (2)], $\gamma_{\mathrm{j}}$ is the effect of date of expected parturition $(\mathrm{j}=1,2,3,4,5,6) ; \rho_{\mathrm{k}}$ is the effect of parity [primi- (1) and multiparous (2)], $\mathrm{S}_{1}$ is the effect of selection line (LFI or HFI); $d_{t}$ is the effect of day ( $t=$ $-5,-4,-2,1,2 \ldots, 15,19) ;(\tau \rho)_{\text {ik }}$ is the interaction between treatment and day; and $\varepsilon_{\mathrm{ijklm}}$ is random error.

The random errors were dependent within an individual and were heteroscedastic for different periods (before and after introduction of the treatment) when $\operatorname{Var}\left(\varepsilon_{\mathrm{ijtklm}}\right)=\sigma_{1}^{2}$, for $\mathrm{t}<0$, and $\operatorname{Var}\left(\varepsilon_{\mathrm{ijtklm}}\right)=\sigma_{2}^{2}$, when $\mathrm{t}$ $>0$. The correlation $\varphi\left[\varepsilon_{\mathrm{ijt}(1) \mathrm{klm}}, \varepsilon_{\mathrm{ijt}(2) \mathrm{klm}}\right]=\varphi_{1}^{1 \mid \mathrm{t}}{ }_{2}-\mathrm{t}_{1}, \mathrm{t}_{1}, \mathrm{t}_{2}<$ $0, \varphi\left[\varepsilon_{\mathrm{ijt}(1) \mathrm{klm}}, \varepsilon_{\mathrm{ijt}(2) \mathrm{klm}}\right]=\varphi_{1}^{1 \mid \mathrm{t}}{ }_{1}-\mathrm{t}_{2}, \mathrm{t}_{1}, \mathrm{t}_{2}>0$ (independent between values before and after introduction of the treatment).

Because the Hp concentrations were below the detection range in all but one cow, they were not tested statistically. The statistical analysis was performed on mean values of 2 or 3 samples before dry-off, and on individual samples after dry-off.

Furthermore, in model 2 (plasma parameters) the time factor $\left(d_{t}\right)$ was divided into 2 classes, defining data as before or during dry-off. The model used different variances between subjects for the 2 period classes and different autoregressive covariance structures for the within-subject variation.

The statistical analysis of milk ATP in milk, using a modified version of model 2 , was performed on the quar- 
Table 1. Least squares means (LSM) and $F$-tests of fixed effects included in the model for heart rate, rectal temperature, rumen contraction and $\mathrm{BCS}^{1}$

\begin{tabular}{|c|c|c|c|c|c|}
\hline \multirow[b]{2}{*}{ Variable } & \multirow[b]{2}{*}{ Period } & \multicolumn{2}{|c|}{ Treatment, LSM $\pm \mathrm{SE}$} & \multicolumn{2}{|c|}{$\begin{array}{c}\text { Fixed effects } \\
P \text {-value }\end{array}$} \\
\hline & & Straw & Silage & $\mathrm{T}$ & G \\
\hline \multirow[t]{2}{*}{ Heart rate, per min } & Prior to dry-off ${ }^{2}$ & $75.4 \pm 1.4$ & $78.3 \pm 1.5$ & \multirow[t]{2}{*}{0.05} & \multirow[t]{2}{*}{0.15} \\
\hline & During dry-off ${ }^{3}$ & $54.8 \pm 1.4$ & $59.7 \pm 1.5$ & & \\
\hline \multirow[t]{2}{*}{ Rectal temperature, ${ }^{\circ} \mathrm{C}$} & Prior to dry-off & $38.4 \pm 0.1$ & $38.6 \pm 0.1$ & \multirow[t]{2}{*}{0.15} & \multirow[t]{2}{*}{0.14} \\
\hline & During dry-off & $38.2 \pm 0.1$ & $38.5 \pm 0.1$ & & \\
\hline \multirow[t]{2}{*}{ Rumen contraction, per min } & Prior to dry-off & $1.6 \pm 0.1$ & $1.5 \pm 0.1$ & \multirow[t]{2}{*}{0.08} & \multirow[t]{2}{*}{0.61} \\
\hline & During dry-off & $1.2 \pm 0.1$ & $1.5 \pm 0.1$ & & \\
\hline \multirow[t]{2}{*}{$\mathrm{BCS}$} & 1 wk prior to dry-off & $4.0 \pm 0.2$ & $3.8 \pm 0.2$ & \multirow[t]{2}{*}{0.96} & \multirow[t]{2}{*}{0.26} \\
\hline & 2 wk prior to parturition & $3.9 \pm 0.2$ & $3.7 \pm 0.2$ & & \\
\hline
\end{tabular}

\footnotetext{
${ }^{1}$ Fixed effects are treatment $(\mathrm{T})$, and group $(\mathrm{G})$.

${ }^{2}$ Sample d -2 .

${ }^{3}$ Sample d 5.
}

ter level. The fixed effects parity, selection line, and date of expected parturition (groups 1 to $6, \mathrm{G}$ ) were found to be nonsignificant and were excluded from the model. The daily milk yield and milk SCC were analyzed using a modified model 2 , and the time factor $\left(\mathrm{d}_{\mathrm{t}}\right)$ was divided into 3 classes, defining data as before dryoff, during dry-off, and PP. Because SCC were not normally distributed, logarithm values were used in the statistical model. The only fixed effects that were significant in the SCC statistical analysis were the effects of $\mathrm{G}$ and day.

The numbers of new IMI (major udder pathogens and all udder pathogens) during dry-off and $\mathrm{PP}$, in relation to before dry-off, were calculated on the cow and udder quarter levels, and differences between treatment groups were evaluated using Fisher's exact test (Statistica, StatSoft Inc., Tulsa, OK).

\section{RESULTS}

\section{Feed and Milk Yield}

Day 1 of dry-off occurred at $67 \pm 15 \mathrm{~d}$ prior to calving. The straw group consisted of 5 primiparous and 6 multiparous cows, whereas the silage group contained 7 primiparous and 3 multiparous cows. The numbers of HFI cows were 5 and 6 in the straw and silage groups, respectively, whereas the corresponding numbers for LFI cows were 6 and 4 cows, respectively. All cows in the silage group consumed their silage ration $(4 \mathrm{~kg} / \mathrm{d}$ of DM) during dry-off. They also consumed $4.8 \pm 0.3$ $\mathrm{kg} / \mathrm{d}$ of DM straw, whereas the straw cows consumed $5.6 \pm 0.7 \mathrm{~kg} / \mathrm{d}$ of DM straw. Because of technical problems, the straw consumption data were based on 12 cows, equally distributed between the 2 treatments.

The average daily milk yield prior to dry-off (means from milkings during the week prior to dry-off) was $16.8 \pm 0.8 \mathrm{~kg}$ and $17.3 \pm 0.8 \mathrm{~kg}$ per cow in the straw and silage groups, respectively. All cows reduced their milk production during dry-off, but there was no significant difference in milk production between dry-off treatments $(P=0.56)$. The straw and the silage cows had milk yields of $9.0 \pm 0.6$ and $9.2 \pm 0.6 \mathrm{~kg}$, respectively, at $\mathrm{d} 3$, and $2.3 \pm 0.3$ and $4.2 \pm 0.6 \mathrm{~kg}$, respectively, at d 5 .

\section{Clinical Findings, BCS, and Disease Incidence}

The results from the $F$-tests of fixed effects included in the statistical model for clinical findings and BCS are presented in Table 1 . The heart rate decreased during dry-off in both treatment groups and was significantly lower in the straw group compared with the silage group. The rectal temperature did not change over time. There was a significant decrease over time in the number of rumen contractions, with numerically lower numbers in the straw group, but the difference between groups was not significant. There were no significant effects on BCS. One cow in the straw group and 2 cows in the silage group developed clinical mastitis within $10 \mathrm{~d}$ PP, but no other clinical diseases were recorded during the experiment.

\section{Plasma Cortisol, Hp, SAA, and Mg}

The results from the $F$-tests of fixed effects included in the statistical model for daily plasma concentrations of cortisol, SAA, and $\mathrm{Mg}$ are shown in Table 2. The daily plasma cortisol concentrations around dry-off are presented in Figure 1. Treatment had a significant effect on the values, with higher concentrations during dry-off in the straw group than in the silage group. The straw group had significantly higher cortisol values at 1 to 6 compared with prior to dry-off. The concentration returned to pre-dry-off values when the cows were introduced to the dry period feed. The cortisol concen- 
Table 2. $P$-values from the $F$-tests of fixed effects included in the model for plasma concentrations of cortisol, serum amyloid A (SAA), and magnesium $(\mathrm{Mg})^{1}$

\begin{tabular}{lcrrrl}
\hline & \multicolumn{5}{c}{ Fixed effects, $P$-value } \\
\cline { 2 - 6 } Item & $\mathrm{T}$ & $\mathrm{G}$ & $\mathrm{P}$ & Day & $\mathrm{T} \times$ day \\
\hline Cortisol & 0.03 & $<0.01$ & 0.60 & $<0.001$ & 0.11 \\
$\mathrm{SAA}$ & 0.37 & 0.04 & $<0.001$ & $<0.001$ & 0.71 \\
$\mathrm{Mg}$ & 0.057 & $\mathrm{NI}$ & $<0.001$ & $<0.001$ & 0.51 \\
\hline
\end{tabular}

${ }^{1}$ Fixed effects are treatment $(\mathrm{T})$, group $(\mathrm{G})$, parity $(\mathrm{P})$, sample day (day), and the interaction between $\mathrm{T} \times$ day. $\mathrm{NI}=$ Not included in the model.

tration was also affected by parity, with a lower level in primiparous $(7.73 \pm 0.82 \mathrm{nM})$ than in multiparous cows $(8.33 \pm 0.83 \mathrm{n} M)$.

Least squares means, calculated on 12 samples per cow and day, for the diurnal cortisol profiles for the straw and silage groups were $7.47 \pm 0.86$ and $8.38 \pm$ $0.91 \mathrm{n} M$, respectively, before dry-off $(\mathrm{d}-4)$, and 14.48 \pm 0.86 and $7.32 \pm 0.91 \mathrm{n} M$, respectively, during dryoff (d 3). The statistical analysis revealed an overall treatment effect $(P<0.001)$. The selection lines had a significant effect on the cortisol diurnal profile $(P<0.02)$, with higher levels in HFI cows $(12.6 \pm 0.9$ $\mathrm{n} M)$ than in LFI cows $(9.7 \pm 0.8 \mathrm{n} M)$.

In all but one cow, the $\mathrm{Hp}$ concentration was below the detection range $(<15 \mathrm{mg} / \mathrm{L})$ during the entire study. Thus, this data set was excluded from the statistical analysis. One cow had values above the detection range $(>2,605 \mathrm{mg} / \mathrm{L})$ both prior to and during dry-off but did not have any signs of clinical disease.

The SAA results are presented in Figure 2. There was no significant effect of treatment, but the SAA concentration increased during dry-off in both groups. However, at d 10 and 15, the SAA values were lower than prior to dry-off. Parity had a significant effect on SAA, because the overall mean during dry-off was higher in primiparous cows $(57.5 \pm 5.0 \mu \mathrm{g} / \mathrm{mL})$ than in multiparous cows $(25.5 \pm 5.7 \mu \mathrm{g} / \mathrm{mL})$.

The $\mathrm{Mg}$ concentrations in plasma are presented in Figure 3. Treatment tended to have an effect on the results, with lower values in the straw group, whereas day had a significant effect, with lower concentrations after dry-off than prior to dry-off in both groups. In addition, parity had a significant effect on $\mathrm{Mg}$, with lower concentrations in primiparous cows $(1.93 \pm 0.03$ $\mathrm{mEq} / \mathrm{L})$ than in multiparous cows $(2.12 \pm 0.03 \mathrm{mEq} / \mathrm{L})$.

\section{Milk SCC, ATP, and Bacteriology}

During the 4 wk prior to dry-off, cow composite SCC were analyzed once weekly and the results of these 4 samples were (log SCC) $4.1 \pm 0.4$ and $4.4 \pm 0.4 / \mathrm{mL}$ for the straw and silage groups, respectively. The log SCC increased significantly $(P<0.0001)$ during the 2 milkings at dry-off compared with prior to dry-off in both

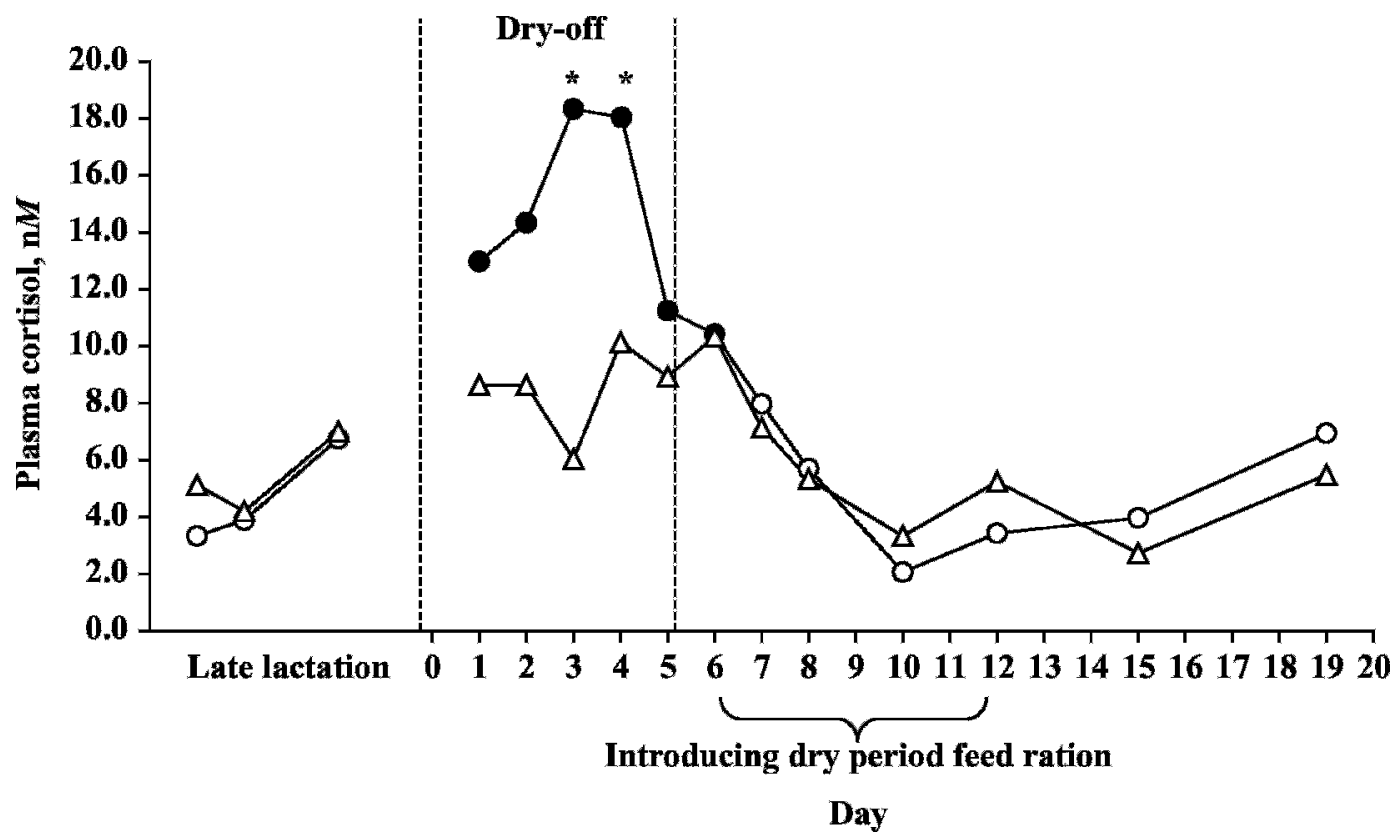

Figure 1. Mean concentrations of cortisol in plasma around dry-off. The symbols represent cows from 2 treatment groups, straw ( $\bigcirc$ ) and silage $(\triangle)$. Values that differ $(P<0.05)$ from prior to dry-off (mean from 3 samples) within treatment are indicated with filled symbols. *Values differ $(P<0.05)$ between treatments on the sampling occasion. The mean SE was 2.3 for straw, and 2.4 for silage. 


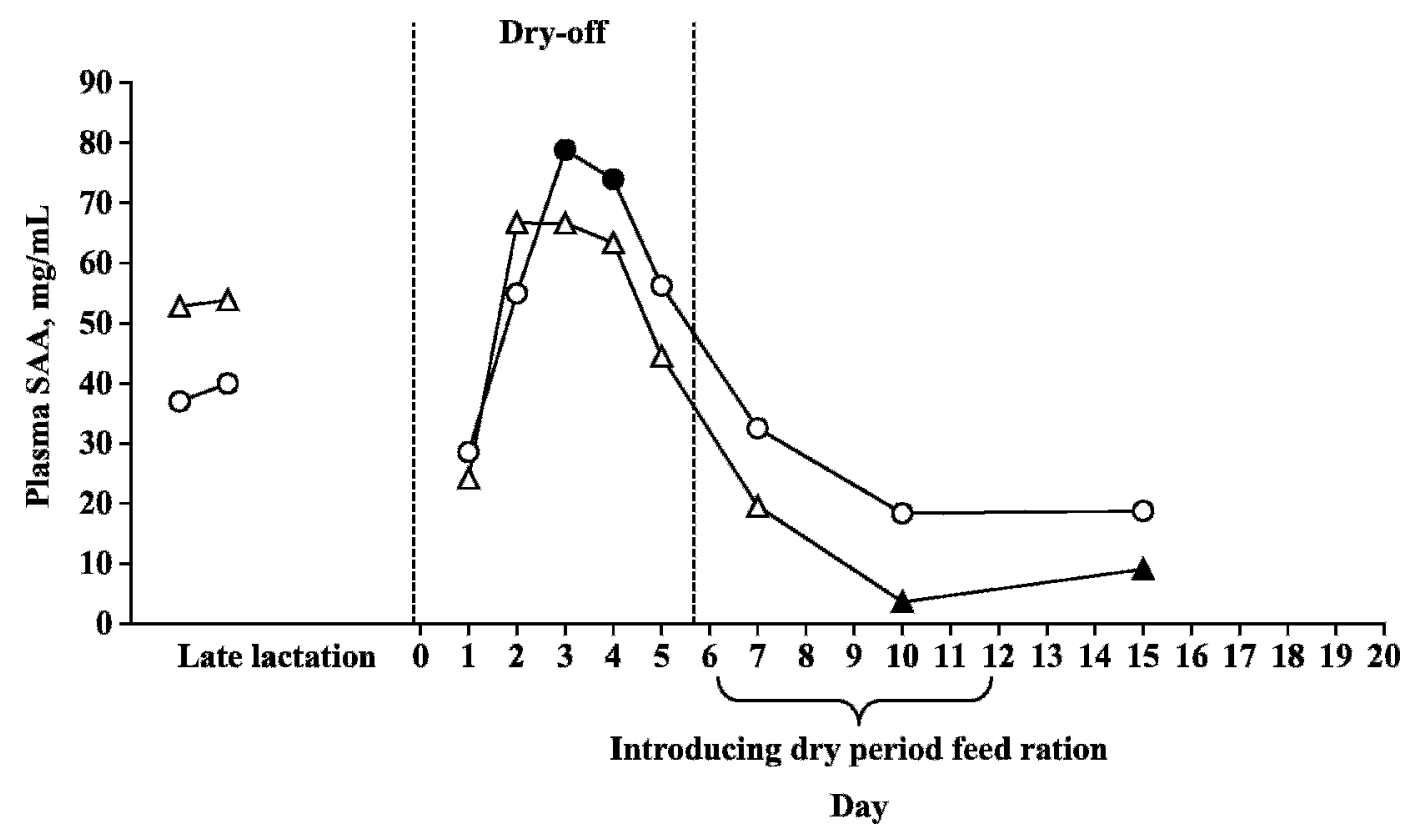

Figure 2. Mean concentrations of serum amyloid A (SAA) in plasma around dry-off. The symbols represent cows from 2 treatment groups, straw $(\bigcirc)$ and silage $(\triangle)$. Values that differ $(P<0.05)$ from prior to dry-off (mean from 2 samples) within treatment are indicated with filled symbols. Treatments did not differ within sampling occasions. The mean SE was 10.1 for straw, and 11.2 for silage.

groups. The log SCC in the straw group were $6.0 \pm 0.4$ and $7.4 \pm 0.4$ per $\mathrm{mL}$ at $\mathrm{d} 3$ and 5 , respectively, whereas the $\log$ SCC in the silage group were $5.6 \pm 0.5$ and 6.7 $\pm 0.5 / \mathrm{mL}$ at $\mathrm{d} 3$ and 5 , respectively. Postparturition, the log SCC in cow composite milk samples decreased again; for the 6 weekly samplings after parturition, they were $3.8 \pm 0.5$ and $4.4 \pm 0.7 / \mathrm{mL}$ for the straw and the silage groups, respectively.

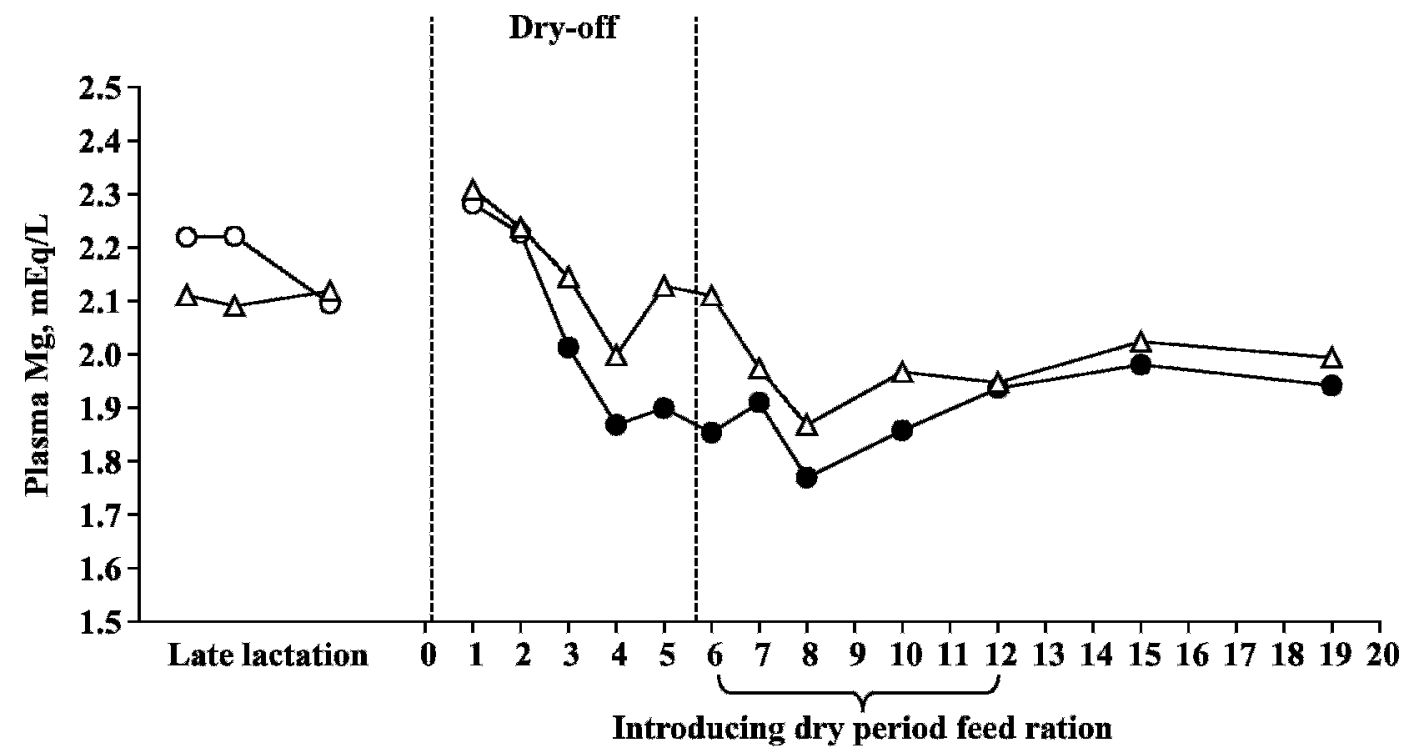

Day

Figure 3. Mean concentrations of magnesium in plasma around dry-off. The symbols represent cows from 2 treatment groups, straw $(\bigcirc)$ and silage $(\triangle)$. Values that differ $(P<0.05)$ from prior to dry-off (mean from 3 samples) within treatment are indicated with filled symbols. Treatments did not differ within sampling occasions. The mean SE was 0.06 for straw and 0.07 for silage. 
Table 3. Least squares means (LSM \pm SEM) and $P$-values from $F$-tests of fixed effects included in the model for milk ATP in the right fore $(\mathrm{RF})$, left fore $(\mathrm{LF})$, right rear (RR), and left rear (LR) udder quarters, respectively ${ }^{1}$

\begin{tabular}{|c|c|c|c|c|c|c|c|c|}
\hline Day & \multicolumn{2}{|c|}{$\mathrm{RF}$} & \multicolumn{2}{|c|}{$\mathrm{LF}$} & \multicolumn{2}{|c|}{$\mathrm{RR}$} & \multicolumn{2}{|c|}{ LR } \\
\hline-5 & $3.2 \pm 0.8$ & $4.8 \pm 0.8$ & $2.9 \pm 0.7$ & $3.1 \pm 0.8$ & $2.8 \pm 1.3$ & $4.2 \pm 1.4$ & $6.9 \pm 3.5$ & $5.9 \pm 3.7$ \\
\hline 3 & $10.6 \pm 6.6$ & $19.8 \pm 6.9$ & $21.3 \pm 8.9$ & $15.4 \pm 9.3$ & $9.1 \pm 17.2$ & $26.9 \pm 18$ & $9.3 \pm 5.4$ & $12.3 \pm 5.6$ \\
\hline 5 & $19.5 \pm 6.6$ & $11.1 \pm 6.9$ & $21.8 \pm 8.9$ & $16.5 \pm 9.3$ & $9.7 \pm 17.2$ & $21 \pm 18$ & $16.3 \pm 5.4$ & $8.3 \pm 5.6$ \\
\hline $\mathrm{PP}^{2}$ & $17.2 \pm 6.6$ & $32.9 \pm 6.9$ & $16.5 \pm 8.9$ & $42.3 \pm 9.3$ & $13.6 \pm 17.2$ & $56.7 \pm 18$ & $17.4 \pm 5.4$ & $40.7 \pm 5.6$ \\
\hline $\mathrm{PP}^{2}$ & $12.3 \pm 6.6$ & $10.8 \pm 7.3$ & $11.3 \pm 8.9$ & $9.7 \pm 9.9$ & $47.6 \pm 17.9$ & $34.7 \pm 18.9$ & $9.2 \pm 5.4$ & $12.4 \pm 5.9$ \\
\hline $\mathrm{T} \times$ day & \multicolumn{2}{|c|}{0.38} & \multicolumn{2}{|c|}{0.42} & $<0.05$ & 0.42 & \multicolumn{2}{|c|}{0.06} \\
\hline
\end{tabular}

${ }^{1}$ Fixed effects are treatment $(\mathrm{T})$, sample day (day) and the interaction between $\mathrm{T} \times$ day.

${ }^{2}$ Samples collected 4 to $8 \mathrm{~d}$ postparturition (PP), but at least $2 \mathrm{~d}$ apart.

Results for milk ATP in udder quarter samples are shown in Table 3. The ATP was not affected by treatment but changed significantly over time in all 4 quarters. During dry-off, all quarters in both groups had higher ATP values than prior to dry-off. At the samplings 4 to $8 \mathrm{~d}$ after parturition, the ATP values were higher than, or similar to, those during dry-off. At the first sampling after parturition, the ATP was numerically higher in the silage group in all 4 udder quarters. However, such a trend was not observed at the second sampling. The $\mathrm{T} \times$ day interaction tended to be significant in the left rear quarters.

The proportions of cows with new IMI (all udder pathogens) during dry-off and PP were 33\% in both treatment groups. Corresponding proportions for udder quarters were 11 and $20 \%$, for the straw and silage groups, respectively. The results did not differ significantly between treatment groups. This was also the case when major udder pathogens only were studied (data not shown). Coagulase-negative staphylococci was the most common finding. Other bacteria detected were Staphylococcus aureus, Streptococcus uberis, Arcanobacterium pyogenes, Escherichia coli, and Enterococcus spp.

\section{DISCUSSION}

One early response to stress is the production of glucocorticoids such as cortisol (Mason, 2000). In the present study the cortisol concentration increased during dry-off only in cows fed straw. It decreased again after the dry period feed ration was introduced. Because the silage cows did not respond with any significant increase in cortisol and the milk production before and during dry-off did not differ between groups, it is not likely that the cessation of milking, resulting in an increased intramammary pressure, induced the observed increase in cortisol. In the present study the daily milk production prior to dry-off was approximately $17 \mathrm{~kg}$, which can be described as moderate production. Thus, it cannot be excluded that cows with a higher production level at dry-off might have been stressed by the cessation of milking. It is reasonable to assume that the elevated cortisol level during dry-off in the straw group was due to feed restriction. This is in agreement with Agenäs et al. (2003) and Barb et al. (1997), who showed that feed deprivation gave rise to an increased plasma level of cortisol in cattle and swine, respectively. In the present study, the $\mathrm{ME}$ intake may be calculated based on data from Odensten et al. (2005) and the ME requirements given in Spörndly (2001).

Assuming no milk production during the dry-off period, the energy deficit in straw cows was approximately $38 \mathrm{MJ}$ of ME/d. However, because the straw cows produced $17.3 \mathrm{~kg}$ of ECM, on average, during the dry-off period, requiring an extra $85 \mathrm{MJ}$ of $\mathrm{ME}$, the energy deficit was considerably larger. The energy intake of silage cows balanced the requirements during the dryoff period, assuming no milk production, but the milk production during the dry-off period gave rise to an accumulated deficit of $105 \mathrm{MJ}$ of $\mathrm{ME}$. The observed higher NEFA concentration in plasma among straw cows probably reflected the negative energy balance (Odensten et al., 2005). However, inflammation or stress might also have contributed to the elevated NEFA level (Holtenius and Holtenius, 1996; Lehtolainen et al., 2003).

In both treatment groups the heart rate decreased at dry-off, but the decrease was more pronounced in the straw group. The bradycardia was probably an effect of the reduced nutrient intake, because a decrease in rumen fill results in a reflex slowing of the heart rate, predominantly because of an increase in parasympathetic tone (Clabough and Swanson, 1989; McGurk et al., 1990). 
The number of rumen contractions decreased at dryoff. We previously showed that the VFA concentration in the ruminal fluid decreased during dry-off concomitant with an increase in ruminal fluid $\mathrm{pH}$, especially among the straw group (Odensten et al., 2005). Such changes of the ruminal fluid may give rise to a reduction in $\mathrm{Mg}$ absorption from the rumen (Giduck and Fontenot, 1987; Giduck et al., 1988). In the present study all cows were fed $20 \mathrm{~g}$ of $\mathrm{Mg}$ daily via a mineral mix also during the dry-off period. Thus, they were fed above the recommended $\mathrm{Mg}$ level, although the DM intake was markedly reduced during the dry-off period (NRC, 2001; Spörndly, 2003). Despite this, the plasma Mg dropped during the dry-off period, especially among the straw group. Magnesium solubility declines sharply as the ruminal $\mathrm{pH}$ rises above 6.5 (Dalley et al. 1997), and it is likely that $\mathrm{Mg}$ transport is further reduced when the VFA concentration drops (Schonewille et al., 1997). In addition, reduced rumen motility might also reduce $\mathrm{Mg}$ absorption. However, the reduction in plasma $\mathrm{Mg}$ at dry-off was modest, and none of the cows were hypomagnesemic. It is possible that the negative effects on $\mathrm{Mg}$ absorption were counteracted by the reduced insulin level in plasma (Miller et al., 1980) and reduced ruminal fluid $\mathrm{NH}_{4}{ }^{+}$(Martens et al., 1988). The Mg concentration was lower in primiparous cows than in older cows, but the reason for this is not clear. In contrast, van Mosel et al. (1991) previously showed that lowparity cows fed a low-Mg diet had a higher concentration of $\mathrm{Mg}$ in plasma than did high-parity cows.

Negative energy balance and high NEFA concentrations have been associated with impairment of the immune system, making the cows more vulnerable to infections, for example, in the udder (Rukkwamsuk et al., 1999; Suriyasathaporn et al., 2000). A negative energy balance has been suggested to act in conjunction with other metabolic or endocrine changes, such as increased cortisol, to decrease immune function (Preisler et al., 1999; Perkins et al., 2001). However, in the present study no differences in APP or udder health were observed between dry-off treatments, but several interesting changes occurred during dry-off.

Plasma Hp did not change during dry-off, but plasma SAA increased markedly during this period. High SAA levels have been found in cows with fatty liver and fatty liver-related peripartum diseases (Katoh, 2002). Kobayashi et al. (2002) showed that cows in late lactation, fed a restrictive diet, responded with an elevated level of NEFA in plasma concomitantly with an accumulation of triglycerides in the liver. Also in this study, the NEFA concentration increased because of feed restriction at dry-off (Odensten et al., 2005). It is reasonable to assume that triglycerides were accumulated in the liver during dry-off and that this might have con- tributed to the observed elevation of SAA. However, there were no differences in plasma SAA between the treatment groups, but plasma NEFA was higher in the straw group (Odensten et al., 2005).

Elevated blood SAA and Hp levels are mostly found during inflammatory conditions, for example, during infections or tissue damage (Murata et al., 2004; Petersen et al., 2004) but can also be detected in cattle subjected to physical stress (Alsemgeest et al., 1995). However, in the present study it appears as though the rise in SAA was not an effect caused by stress, because the silage cows also had an increased level of SAA although the cortisol level, indicating stress, was not elevated. The involution of the udder is a form of inflammatory reaction, which is likely to induce a systemic release of APP. However, the most plausible explanation is that such a reaction would result in an increase in both SAA and Hp. An increase in both SAA and Hp is observed after calving, probably because of inflammatory reactions in the reproductive tract associated with involution of the uterus (Uchida et al., 1993; Meglia et al., 2005). It is intriguing that the concentration of SAA, but not that of Hp, was higher before dry-off than in the dry period. The animal's response to moving from one stable to another or to insertion of a jugular vein catheter should have induced an increase in both APP. Thus, it may be speculated that the higher SAA in late lactation was due to metabolic differences between the 2 periods. To our knowledge, this is the first time APP have been measured at dry-off in dairy cows. The increase in SAA without any indication of disease makes this APP unsuitable as a health indicator at this time.

It may be argued that feeding extra silage at dry-off could result in a higher milk production at dry-off and a slower involution of the udder, increasing the risk for udder infections. However, such an effect was not observed in the present study, because neither cow composite SCC nor udder quarter ATP differed significantly between feeding groups during dry-off or in early lactation. Moreover, the proportions of new IMI were similar in the 2 groups. Thus, the results indicate that the observed metabolic differences between groups, for example, in cortisol and NEFA, did not affect the susceptibility to udder infections. However, because the number of cows included in the study was low, it is necessary to confirm the results in studies that include a larger number of animals.

In line with an earlier study (Emanuelson et al., 1988), the SCC increased significantly at dry-off at both the cow and quarter levels. In healthy udders this is mainly a concentration effect as the milk production decreases and cells migrate to the involuting udder. However, there is also an increased risk of IMI during 
this time, which results in an increase in SCC (Dingwell et al., 2004). An increased IMI was also observed in the present study, with one-third of the cows having a new IMI at dry-off. High milk production at dry-off is associated with an increased risk of udder infections and clinical mastitis, most likely because of incomplete closure of the teat canal, sometimes observed as milk leakage (Jørstad et al., 1989; Dingwell et al., 2004; RajalaSchultz et al., 2005). Milk leakage was observed during dry-off in 6 cows equally distributed between the treatment groups (data not shown), but none of these cows was diagnosed with clinical mastitis. According to Rajala-Schultz et al. (2005), the odds of a cow being infected by environmental organisms at calving increase by $77 \%$ with every $5 \mathrm{~kg}$ increase of milk yield at dryoff over $12.5 \mathrm{~kg}$ of milk.

\section{CONCLUSIONS}

Cows fed straw only during dry-off responded with an increased plasma level of cortisol. The elevated cortisol was most likely caused by nutrient insufficiency and not by cessation of milking. It is probable that the increased cortisol level facilitated the coordinated release of nutrients from the peripheral tissues to support the needs of the animal during nutrient insufficiency. Dry-off gave rise to an increased plasma level of SAA both in strawand silage-fed cows. The involution of the udder is an inflammatory reaction that may have contributed to the increase in SAA. The rise in SAA occurred without any indication of disease, which makes this APP unsuitable as a health indicator at this time. Overall, this study and a previous report (Odensten et al., 2005) showed that the common dry-off procedure of feeding straw only may give rise to metabolic disturbances. However, this might be avoided without any apparent negative effects on udder health if a limited amount of silage is added during dry-off.

\section{ACKNOWLEDGMENTS}

Financial support from the Swedish Farmers Foundation for Agricultural Research (No. 0230021) and Animal Welfare for Quality in Food Production project at the Swedish University of Agricultural Sciences are gratefully acknowledged.

\section{REFERENCES}

Agenäs, S., K. Dahlborn, and K. Holtenius. 2003. Changes in metabolism and milk production during and after feed deprivation in primiparous cows selected for different milk fat content. Livest. Prod. Sci. 83:153-164.

Alsemgeest, S. P., H. C. Kalsbeek, T. Wensing, J. P. Koeman, A. M. van Ederen, and E. Gruys. 1994. Concentrations of serum amyloid-A (SAA) and haptoglobin (HP) as parameters of inflammatory diseases in cattle. Vet. Q. 16:21-23.
Alsemgeest, S. P., I. E. Lambooy, H. K. Wierenga, S. J. Dieleman, B. Meerkerk, A. M. van Ederen, and T. A. Niewold. 1995. Influence of physical stress on the plasma concentration of serum amyloidA (SAA) and haptoglobin (Hp) in calves. Vet. Q. 17:9-12.

Barb, C. R., R. R. Kraeling, G. B. Rampacek, and C. R. Dove. 1997. Metabolic changes during the transition from the fed to the acute feed-deprived state in prepuberal and mature gilts. J. Anim. Sci. 75:781-789.

Clabough, D. L., and C. R. Swanson. 1989. Heart rate spectral analysis of fasting-induced bradycardia of cattle. Am. J. Physiol. 257:1303-1306.

Dalley, D. E., P. Isherwood, A. R. Sykes, and A. B. Robson. 1997. Effect of in vitro manipulation of $\mathrm{pH}$ on magnesium solubility in ruminal and caecal digesta in sheep. J. Agric. Sci. 129:107-111.

Dingwell, R., D. Kelton, K. Leslie, and V. Edge. 2001. Deciding to dry-off: Does level of production matter? Pages 69-79 in Natl. Mastitis Counc. Annual Mtg. Proc., Ontario, Canada. National Mastitis Council, Arlington, VA.

Dingwell, R. T., K. E. Leslie, Y. H. Schukken, J. M. Sargeant, L. L. Timms, T. F. Duffield, G. P. Keefe, D. F. Kelton, K. D. Lissemore, and J. Conklin. 2004. Association of cow and quarter-level factors at drying-off with new intramammary infections during the dry period. Prev. Vet. Med. 63:75-89.

Emanuelson, U., T. Olsson, T. Mattila, G. Astrom, and O. Holmberg. 1988. Effects of parity and stage of lactation on adenosine triphosphate, somatic cell count and antitrypsin content in cows' milk. J. Dairy Res. 55:49-55.

Giduck, S. A., and J. P. Fontenot. 1987. Utilization of magnesium and other macrominerals in sheep supplemented with different readily fermentable carbohydrates. J. Anim. Sci. 65:1667-1673.

Giduck, S. A., J. P. Fontenot, and S. Rahnema. 1988. Effect of ruminal infusion of glucose, volatile fatty acids and hydrochloric acid on mineral metabolism in sheep. J. Anim. Sci. 66:532-542.

Holtenius, P., and K. Holtenius. 1996. New aspects of ketone bodies in energy metabolism of dairy cows: A review. J. Vet. Med. 43:579-587.

Jørstad, A., T. B. Farver, and H. Riemann. 1989. Teat canal diameter and other cow factors with possible influence on somatic cell counts in cow milk. Acta Vet. Scand. 30:239-245.

Katoh, N. 2002. Relevance of apolipoproteins in the development of fatty liver and fatty liver-related peripartum diseases in dairy cows. J. Vet. Med. Sci. 64:293-307.

Kobayashi, Y., C. K. Boyd, B. L. McCormack, and M. C. Lucy. 2002. Reduced insulin-like growth factor-I after acute feed restriction in lactating dairy cows is independent of changes in growth hormone receptor 1A mRNA. J. Dairy Sci. 85:748-754.

Lehtolainen, T., S. Suominen, T. Kutila, and S. Pyörälä. 2003. Effect of intramammary Escherichia coli endotoxin in early- vs. latelactating dairy cows. J. Dairy Sci. 86:2327-2333.

Martens, H., G. Heggemann, and K. Regier. 1988. Studies on the effect of $\mathrm{K}, \mathrm{Na}, \mathrm{NH} 4^{+}, \mathrm{VFA}$ and $\mathrm{CO}_{2}$ on the net absorption of magnesium from the temporarily isolated rumen of heifers. J. Vet. Med. A 35:73-80.

Mason, W. A. 2000. Early developmental influences of experience on behavior, temperament and stress. Pages 269-290 in The Biology of Animal Stress: Basic Principles and Implications for Animal Welfare. G. P. Moberg and J. A. Mench, ed. CABI Publishing, New York, NY.

McGuirk, S. M., R. M. Bednarski, and M. K. Clayton. 1990. Bradycardia in cattle deprived of food. J. Am. Vet. Med. Assoc. 196:894-896.

Meglia, G. E., A. Johannisson, S. Agenas, K. Holtenius, and K. P. Waller. 2005. Effects of feeding intensity during the dry period on leukocyte and lymphocyte sub-populations, neutrophil function and health in periparturient dairy cows. Vet. J. 169:376-384.

Miller, J. K., F. C. Madsen, D. E. Lentz, W. O. Wong, N. Ramsey, C. E. Tysinger, and S. L. Hansard. 1980. Blood plasma magnesium, potassium, glucose, and immunoreactive insulin changes in cows moved abruptly from barn feeding to early spring pasture. J. Dairy Sci. 63:1073-1079.

Murata, H., N. Shimada, and M. Yoshioka. 2004. Current research on acute phase proteins in veterinary diagnosis: An overview. Vet. J. 168:28-40. 
NRC. 2001. Nutrient Requirements of Domestic Animals, Nutrient Requirements of Dairy Cattle. 7th rev. ed. National Academy of Sciences, Washington, DC.

Odensten, M. O., Y. Chilliard, and K. Holtenius. 2005. Effects of 2 different feeding strategies during dry-off on metabolism in highyielding dairy cows. J. Dairy Sci. 88:2072-2082.

Olsson, T., K. Sandstedt, O. Holmberg, and A. Thore. 1986. Extraction and determination of adenosine $5^{\prime}$-triphosphate in bovine milk by the firefly luciferase assay. Biotechnol. Appl. Biochem. 8:361-369.

Perkins, K. H., M. J. VandeHaar, R. J. Tempelman, and J. L. Burton. 2001. Negative energy balance does not decrease expression of leukocyte adhesion or antigen-presenting molecules in cattle. J. Dairy Sci. 84:421-428.

Petersen, H. H., J. P. Nielsen, and P. M. Heegaard. 2004. Application of acute phase protein measurements in veterinary clinical chemistry. Vet. Res. 35:163-187.

Preisler, M. T., P. S. D. Weber, R. J. Tempelman, R. J. Erskine, H. Hunt, and J. L. Burton. 1999. Glucocorticoid receptor downregulation in neutrophils of periparturient cows. Am. J. Vet. Res. 61:14-19.

Rajala-Schultz, P. J., J. S. Hogan, and K. L. Smith. 2005. Association between milk yield at dry-off and probability of intramammary infections at calving. J. Dairy Sci. 88:577-579.
Rukkwamsuk, T., T. A. Kruip, and T. Wensing. 1999. Relationship between overfeeding and overconditioning in the dry period and the problems of high producing dairy cows during the postparturient period. Vet. Q. 21:71-77.

Schonewille, J. T., L. Ram, A. T. Van't Klooster, H. Wouterse, and A. C. Beynen. 1997. Native corn starch versus either cellulose or glucose in the diet and the effects on apparent magnesium absorption in goats. J. Dairy Sci. 80:1738-1743.

Skidmore, A., K. Peeters, C. Sniffen, and A. Brand. 1997. Monitoring dry period management. Pages 171-201 in Herd Health and Production Management in Dairy Practice. A. Brant, J. Noordhuizen, and Y. Schukken, ed. Wageningen Pers, Wageningen, the Netherlands.

Spörndly, R. 2003. Fodertabell för idisslare. Rapport 257. Dept. of Anim. Nutr. and Management, Swedish Univ. Agric. Sci., Uppsala, Sweden (in Swedish).

Suriyasathaporn, W., C. Heuer, E. N. Noordhuizen-Stassen, and Y. H. Schukken. 2000. Hyperketonemia and the impairment of udder defense: A review. Vet. Res. 31:397-412.

Uchida, E., N. Katoh, and K. Takahashi. 1993. Appearance of haptoglobin in serum from cows at parturition. J. Vet. Med. Sci. 55:893-894.

van Mosel, M., A. T. van't Klooster, and H. S. Wouterse. 1991. Effects of a deficient magnesium supply during the dry period on bone turnover of dairy cows at parturition. Vet. Q. 13:199-208. 